\title{
ARE HOLOCAUST VICTIMS JEWISH? LOOKING AT PHOTOGRAPHS IN THE IMPERIAL WAR MUSEUM HOLOGAUST EXHIBITION
}

\author{
K. Hannah Holtschneider*
}

\begin{abstract}
This essay argues that the representation of Jewish identifications in the permanent Holocaust exhibition in the Imperial War Museum, London, tries to balance the self-representation of Jewish victims with the demands of a perpetrator-led narrative that by necessity characterises Jews in antisemitic terms. The analysis is based on close readings of the exhibition, in particular of the photographic displays, archival sources and interviews with curators. Ultimately, the exhibition is unable to represent Jewish victims of the Holocaust as subjects with agency, because it focuses on the process of destruction at the expense of expounding on what was destroyed. This may be inevitable in a Holocaust exhibition. Nonetheless, the article poses the question whether such an approach has the consequence of unwittingly perpetuating antisemitic representations of Jews and Jewishness.
\end{abstract}

The Holocaust exhibition at the Imperial War Museum, London (IWM), opened to the public in the summer of 2000, proclaims in its statement of purpose that it understands the Holocaust primarily as the genocide of European Jews, though the fact that the Nazis also persecuted and murdered millions of non-Jews, albeit in arguably less systematic ways, is referenced. This is the wording opening the permanent Holocaust exhibition at the IWM:

Under the cover of the Second World War, for the sake of their 'New Order', the Nazis sought to destroy all the Jews of Europe. For the first time in history, industrial methods were used for the mass extermination of a whole people. Six million people were murdered, including 1,500,000 children. This event is called the Holocaust. The Nazis enslaved and murdered millions of others as well. Gypsies, people with physical and mental disabilities, Poles, Soviet prisoners of war, trade unionists, political opponents, prisoners of conscience, homosexuals, and others were killed in vast numbers. This exhibition looks at how and why these things happened. (IWM January 2008)

Since the Holocaust is seen chiefly as the exclusion, persecution and murder of Jews, I am interested to understand how the exhibition communicates who 'Jews' are in the conceptualisation of the IWM. The analysis is concerned with the IWM's interpretation of what is 'Jewish', that is, the complex nexus of ethnicity, culture, religion, language which articulates people's identifications and belonging, both as they see themselves and as they are seen by others. The representations of Jewishness offered by the IWM Holocaust exhibition need to establish for visitors who the victims of the Holocaust were. To do so, the exhibition employs visual and textual clues which link with the visitors' image of Jews. Only then can the exhibition hope to facilitate learning about the people who became victims, confirming, challenging and/or subverting preconceptions visitors may hold about Jews. What is

\footnotetext{
* Senior Lecturer in Jewish Studies, School of Divinity, University of Edinburgh. Email: H.Holtschneider@ ed.ac.uk
} 
imagined to be 'normatively' Jewish and thus recognisably such for the visitor, is therefore a question guiding the explorations in this paper. I will explore the techniques the museum uses to establish the ethnic and/or cultural identity of the Jewish victims through an analysis of photographic displays in the IWM Holocaust exhibition.

Before we turn to an analysis of photographic displays, we need briefly to examine the relationship of photography to the events of the Holocaust and how this may have a bearing on the 'musealisation' of the Holocaust.

\section{Photography and the Holocaust}

World War II quickly became the most photographed battleground to date, photography not only being used officially to document or by journalists to report, but increasingly by individual soldiers who recorded 'their war' on personal hand-held cameras, widely available and affordable by the late 1930s. Merchandise allowing the collection and display of 'my war' became even more popular than during World War I, with soldiers swapping and selling photos with their comrades and sending them home as postcards which reported their news from the battlefield.

Professional photographers in the Propagandakompanie $(P K)$ took pictures mainly of Eastern European Jews during the war and published these in magazines such as the Berliner Illustrirte. These photo essays were conceptualised and arranged in such a way that they clearly exhibit aspects of Nazi antisemitism and make ideological statements about the status of Jews in Nazi thinking. ${ }^{.}$Soldiers of the Wehrmacht as well as members of the SS and Einsatzgruppen who were keen amateur photographers took their cues from these papers and imitated the style and perspective exhibited there by professionals serving the ends of the party and the government. ${ }^{2}$

The Holocaust was photographed, despite prohibitions against private individuals doing so. Members of the Propagandakompanie, employed specifically to record photographic evidence of the destruction of the Jewish enemy, needed the co-operation of the squads of soldiers they worked with. One way to ensure co-operation was the trading of images produced by the professional photographers with the soldiers they accompanied on their murderous missions. Another was the developing and printing of photographs taken by the soldiers themselves. Both activities defied the prohibition on taking photographs, but it was this which led to the widespread availability of images of atrocity involving German soldiers from the Wehrmacht, SS and Einsatzgruppen. These photographs constitute a significant part of the material evidence of the genocide, in particular in terms of representations of its victims whose lives were so thoroughly destroyed that material objects speaking to their lives are largely lacking. However, their emplotment in Holocaust exhibitions, as we will see, is not uncontested. ${ }^{3}$

\footnotetext{
${ }^{1}$ Loewy, Hanno, “ “... without Masks”: Jews through the Lens Of “German Photography” 1933-1945’ In German Photography 1870-1970: Power of a Medium, eds., Klaus Honnef, Rolf Sachsse, and Karin Thomas (Köln DuMont Buchverlag, 1997), 111.

2 Loewy, "without Masks" ' in Honnef, Sachsse, and Thomas, eds., German Photography 1870-1970, $106 \mathrm{f}$.

3 The visual representation of the Holocaust continues to be a contested field. A concern permeating much writing on the representation of the Holocaust is the notion of its 'unrepresentability'. The present context does not allow (nor call for) an exploration of the debate about possibilities and limitations to the visual representation of the
} 
The curators of the IWM exhibition are trained historians. ${ }^{4}$ A design company provided the plans for the use of the layout of the available exhibition space and worked with the curators to translate the historical narrative provided into an exhibition with a clear pathway and carefully composed displays. To understand the use of photographs of victims in the IWM exhibition, it is necessary briefly to consider the functions of photos in historical research.

Historians work with the indexicality of the photograph, that is, they use images to look for signs of a past reality. Photographs are ambiguous historical documents or sources and have only recently begun to receive serious attention from historians as sources/documents in their own right. A prominent reason for this difficult status is the fact that they can be infinitely reproduced - raising questions about what constitutes an original - and a second reason is the fact that they can be manipulated. In common with other historical documents photographs always embody a point of view, they have an author and a perspective. They are interpretations of a reality which was different before the shutter came down and which changed immediately after that moment. Photographs are often viewed as direct references to a past reality, as if seeing an image gives access to what is pictured in an unmediated way. And yet, we know that photographs can be manipulated and that this has been done since the inception of the technique which fixes images on paper. Indeed, that a photograph can be altered was (and is) an attraction, the fact that we can make ourselves look more beautiful than we seem in reality through a few simple changes to an image always was a powerful aspect of photography, well before the invention of photoshop. Photographs are not neutral, they are not a straightforward reproduction of reality.

If photographs are understood as interpretations of reality, what matters to a historian is not only a consideration of the technology and technique of producing particular images and the relation of the subject that has thus been rendered visible, but also the history of a photograph's reproduction, distribution and display. Connected to this are questions regarding the meaning assigned to a photograph. Meanings are created through the relationship between the viewer and the image. This relationship undergoes changes from the moment the shutter is pressed. The interpretation of the scene through the viewfinder is different from the meaning the photograph has to its author on first viewing it on paper. And the meaning shifts again at subsequent viewings. Different meanings are assigned by other people who view the image in a variety of contexts. For example, a portrait of a soldier in the battlefield can be used as a documentation of 'I was here'; it can be seen as an evocation of his presence in the home of his family who received that image from the battlefield; it

Holocaust. The Holocaust is subject of major exhibition projects which prove popular with the general public and have become important educational tools, and as such is represented with the help of visual media. Only the method and a/effects of one aspect of a specific example of the musealisation of the Holocaust are the topic of this paper.

${ }^{4}$ The Holocaust Exhibition Project Team at the IWM continues to be led by historian Suzanne Bardgett. By contrast, the United States Holocaust Memorial Museum's exhibition was put together under the leadership of Shaike Weinberg, whose background was in theatre and performance and who had previously curated the exhibition at Tel Aviv's Diaspora Museum, Bet Hatefutsoth. This latter exhibition pioneered the approach of 'a museum without objects', configuring a museum as 'story telling in a three-dimensional space' which relies on the visitor's total immersion with all senses in the exhibition narrative. Using simulation techniques, Weinberg stressed the performative aspect of a museum, treating the exhibition as a 'Gesamtkunstwerk' that has to be experienced in its totality, thus decidedly moving away from traditional exhibition strategies of carefully arranged showcases with labelled objects. 
could commemorate his life if he was killed in action; it can forge a relation to a different period of history if viewed today, acting as a springboard for imagining a historically distant life which looks deceptively close due to the lifelike features of a photograph. While the actual image does not change, its uses do and thereby its meaning. Looking at historical photographs today means that we are often looking at people who were dead before we were born and their photographs relate a moment which has been and gone and which we are only able to read with the knowledge that that person is no more, or who, if they are still alive, may no longer bear much physical resemblance to the person represented.

\section{Exhibiting the Holocaust}

History museums and exhibitions split into different genres of exhibiting the past. Traditional exhibitions show objects of historical interest assembled, categorised and labelled, and leave the visitor to chart their own path through the exhibition area. Current preference in the design of Holocaust exhibitions favours narrative and memorial exhibitions, each making slightly different demands on the visitor. ${ }^{5}$

Narrative exhibitions lead the visitor through a historical topic mostly in a linear fashion, so that competing interpretations of the historical evidence are often obliterated in favour of the presentation of one authoritative master narrative. The visitor has hardly any opportunity to deviate from the path of the exhibition and the dominant narrative seeks to provide the audience with a self-contained and accessible story. Many such exhibitions are object-led in the sense that historical artefacts are presented as access points to an experience of the past. Some exhibitions also work with emotive devices such as walk-in recreations of historical spaces, puppets, or sounds and smells to enable the visitor to experience an illusion of the past. In this respect historical exhibitions compete with the heritage industry which employs similar strategies to create 'experiences of history' in actual historical settings or in recreations of historical environments. ${ }^{6}$

Memorial museums not only endeavour to provide a historical narrative, but also enable the commemoration of historical events and people by those most closely connected to the subject of the exhibition. Thus memorial museums aim at two different audiences: at those who seek commemoration and at those who seek education about the history in question. The educational aspects of such exhibitions are akin to the strategies employed by narrative museums, while the architectural surroundings and the placement of artefacts serve as spaces and guides for commemoration. ${ }^{7}$

\footnotetext{
5 A leading example for a narrative and memorial exhibition is the USHMM. For the following see Katrin Pieper, Musealisierung des Holocaust: Das füdische Museum Berlin und das U.S. Holocaust Memorial Museum in Washington D.C. Ein Vergleich (Köln: Böhlau Verlag, 2006), $29 f$.

${ }^{6}$ Stephen Greenberg, 'The Vital Museum' in Suzanne MacLeod, ed., Reshaping Museum Space: Architecture, Design, Exhibition, Museum Meanings (London: Routledge, 2005), 230-233.

${ }^{7}$ For example, the USHMM seeks to achieve an authoritative narration of the history of the Holocaust and at the same time serves as a space for commemoration of the victims of the Holocaust by individuals and groups. The USHMM has some spaces dedicated specifically to memorialisation. One might argue that the entire museum is a commemorative space and that all objects displayed therein can be invested with commemorative value. Cf. Oren Baruch Stier, Committed to Memory: Cultural Mediations of the Holocaust (Amherst, MA: University of Massachusetts Press, 2003); Andrea Liss, Trespassing through Shadowes: Memory, Photography, and the Holocaust (Minneapolis, MN University of Minnesota Press, 1998).
} 
Holocaust museums and exhibitions share in both strategies of musealising historical topics, though the aspects which invite visitors to imagine themselves as part of the narrative exhibited are carefully limited so as not to offer a chamber of horrors or to violate the memory of the victims. The latter is an important aspect of debates surrounding exhibits, such as what can be displayed and how. Holocaust exhibitions are universally constructed with educational objectives which aim to provide learning opportunities relevant to the context of the visitors' lives, while informing visitors about the history of the genocide of European Jews. Thus visitors are supposed to connect the narrative of the exclusion, persecution and murder of Jews with current social-political debates about xenophobia, immigration and racism. The exhibitions themselves may not necessarily make those connections explicitly (though some do, for example Museum of Tolerance - Beith Hashoah, Anne Frank House Amsterdam). However, educational materials aimed at teenage visitors (often as part of organised school visits) suggest that learning about the Holocaust offers lessons which can be applied to the immediate context of the teenagers' lives. ${ }^{8}$

In German academia there is a growing body of writing which addresses the question of history teaching in museums. Pedagogical concerns are joined with the craft of the historian and curator to communicate 'history'. In a recent study entitled Visual History und Geschichtsdidaktik, ${ }^{9}$ Christoph Hamann seeks to do two things: to offer an interpretation or understanding of historically significant photographs and to facilitate an interpretation of reality which takes place through/in photographs, that is, to consider photographs in relation to particular cultures of looking and the gaze as they relate to particular images.

Hamann judges that younger visitors to museum exhibitions are used to much higher levels of regular visual stimulation than previous generations, while also finding that their visual literacy, that is their ability to interpret images, does not seem to have increased to the same degree. ${ }^{10}$ This lack of critical viewing ability poses a problem to those interested in teaching history through images, a strategy that Holocaust exhibitions rely on. Rather than giving rise to questions about the historical period that is exhibited, photographs appear to be perceived as visual confirmation of previously held ideas. Hamann thus concludes that photographs are literally 'not seen'.

Hamann's work raises questions with regard to the ability of museum visitors to 'read' photographs critically, and concerns the wider context of the production of exhibitions which rely to a significant extent on photographs to support and convey their narrative. Holocaust exhibitions consider visitor groups who are used to much higher visual stimulation than the curators building the exhibition are used to. Curators often are historians (as in the IWM), whereas professionals trained in museum studies are still too new on the scene to constitute a majority among those conceptualising and researching exhibitions. This is true in regard to the IWM Holocaust exhibition which was curated in the late 1990s, for instance. When we consider this together with the fact that historians until very recently only reluctantly considered photographs as historical sources, we might usefully wonder whether curators actually bring a more developed visual literacy to the exhibitions than their young visitors.

\footnotetext{
8 The tendency to encourage such connections has been criticised, in particular as it explicitly instrumentalises the Holocaust for contemporary political aims.

${ }_{9}^{9}$ Christoph Hamann, Visual History und Geschichtsdidaktik: Bildkompetenz in der historisch-politischen Bildung, Geschichtswissenschaft 53 (Herbolzheim: Centaurus Verlag, 2007).

${ }^{10}$ Hamann, Visual History und Geschichtsdidaktik), 37f.
} 
Another concern, relating not specifically to the use of photographs but more broadly to the representation of the Holocaust in exhibitions, is raised by Dirk Rupnow. His study Vernichten und Erinnern has recently shown in detail that the Nazis' own plans to 'memorialise' Jews were far advanced, not least through archival projects at institutions promoting 'Judenforschung', whose employees researched and published on Jewish history from an antisemitic perspective, and through planned exhibitions and museums. The best known among these museum projects was the planned Jewish museum in Prague, which was supposed to exhibit the remnants of Jewish culture(s) in Europe, authoritatively emplotted in a Nazi antisemitic narrative. ${ }^{11}$ Rupnow studied the ways in which the Nazi government encouraged the collection of Jewish ritual objects, written sources and visual evidence of Jewish life alongside the accumulation of evidence documenting the murder of Jews. 'Judenforschung' aimed at the preservation of a particular perspective on Jewish history, inscribing an antisemitic 'normativity' in the representation of Jews for the purposes of perpetuating and justifying antisemitism: the photographic evidence of the persecution of Jews and their murder was supposed to illustrate the necessity of the annihilation of Jewish life and culture.

What is significant in relation to my contribution is the challenge Rupnow raises to contemporary musealisations of the Holocaust. He asks whether it is possible that the intricate connections the Nazis drew between their crimes and the history of their victims may have been replicated in contemporary forms of Holocaust remembrance and representation, ${ }^{12}$ such that the antisemitic 'normativity' of Nazi representations of Jews can be found in contemporary Holocaust exhibitions. Rupnow hints at this possibility because many Holocaust exhibitions explicitly rely on evidence produced by the vicitimisers to document the process of murder, and because exhibitions often employ a perpetrator-led narrative. The IWM is no exception here. Hence, we may well ask whether it is possible that the IWM exhibition may rely too uncritically on perpetrator evidence to represent the lives and deaths of the victims. With these considerations in mind we now turn to the permanent Holocaust exhibition at the IWM London.

\section{Representations of Jewishness in the IWM Holocaust exhibition}

The IWM Holocaust exhibition unfolds in a linear narrative on two floors. ${ }^{13}$ The upper floor considers Nazi ideology, discriminatory legislation, intimidation, persecution, emigration and violence, culminating in the move towards murder in the T4 euthanasia programme. Descending to the lower floor, the exhibition continues with the beginning of war, the invasion of the Soviet Union, and the ensuing process of murder through Einsatzgruppen, ghettos, Aktion Reinhard, Auschwitz-Birkenau, slave labour, rescue and resistance, to the end of the war and war crimes trials. The organisation of the material deliberately allows the perspective of the murderers to guide the visitor through the history of persecution and murder, because this allows the development of a storyline which gives a common purpose

\footnotetext{
11 Dirk Rupnow, Vernichten und Erinnern: Spuren Nationalistischer Gedächtnispolitik (Göttingen: Wallstein, 2005).

${ }^{12}$ Rupnow, Vernichten und Erinnern, $339 f f$.

${ }^{13}$ For a discussion of this presentation strategy which is prevalent in most Holocaust exhibitions cf. Pieper, Musealisierung des Holocaust, 29f.
} 
to seemingly disparate events. The narrative is illustrated with artefacts, photographs and testimony from victims. Throughout the exhibition, survivor testimony accompanies the narrative at every stage except in the display on the Einsatzgruppen and Jewish resistance. Thus video and audio testimonies from survivors (mostly Jewish) who are today living in Britain describe impressions of pre-war life, the discrimination following the Nuremberg Laws, persecution of Jews in Poland, life in the ghettos, deportation, the murder process and life in Auschwitz-Birkenau, slave labour, liberation and reflections on life after the Holocaust.

Photographs play an important part in this musealisation of the Holocaust, functioning as evidence and illustration. Photo murals dominate entire walls and the background of display cases, setting the tone and creating the atmosphere, communicating that 'this has been'. Photos represent both the victims before they became victims and their dehumanisation and murder. According to the curators, photographs are supposed to bring home 'the truth' or 'the reality' of the process of persecution and murder. ${ }^{14}$ The vast majority of photographic evidence and images of victims shown in the exhibition was produced by perpetrators. There are images which depict violence which were taken by victims themselves, but these are rare and not always identified as such (an exception are the photographs taken clandestinely and under great danger by the Sonderkommando in Birkenau in 1944 and then smuggled out of the camp, which are displayed and discussed on a separate panel).

The IWM does not operate a censorship policy on photographs which are deemed too violent or pornographic, unlike the United States Holocaust Memorial Museum in Washington, DG (USHMM). The IWM curators wished to avoid the 'peep show' effect produced by the screens at the USHMM behind which images too gruesome for open display are visible. ${ }^{15}$ Rather, the curators suggest that by the time visitors reach photographs of atrocities such as the humiliation of Jews in Poland, as well as the crimes committed by or alongside the Einsatzgruppen, they will have been adequately prepared to be able to cope with images such as those of recently violated women photographed on the streets of Lvov. ${ }^{16}$ The curators argue that such images need to be exhibited, because they are witnesses to the reality of the events. At the same time, the curatorial team decided not to include an 'evidence layer' which would have commented on the origins of the objects and photographs in the exhibition, the reason being that visitors should not have to deal with too much text. Limiting text in exhibitions has well-founded museological reasons, since an exhibition is not 'a book on a wall'. An exhibition is supposed to engage various senses and appeal to a variety of audiences whose literacy levels differ. Hence the use of space, the placement of objects, images and text in relation to each other is what creates an 'exhibition experience', something that would be lost if visiting an exhibition is akin to reading a book. However, the curators argue that the history of the Holocaust needs to be displayed in an authoritative linear narrative, so that the visitor is able to learn exactly that which the curators wish to impart. They reject the option that this exhibition should offer opportunities to reflect critically on

\footnotetext{
${ }^{14}$ Interview with Suzanne Bardgett, IWM Holocaust Exhibition Project Director, 1 July 2008; interview with James Taylor and Paul Salmons, IWM, 4 July 2008.

${ }^{15}$ Interview with James Taylor and Paul Salmons, IWM, 4 July 2008.

16 Thus the extremely shocking and challenging quality of evidence of the Holocaust is contained so the exhibition narrative can be assimilated without traumatising the visitors. Cf. Stephen Greenberg, 'The Vital Museum' in Suzanne MacLeod, ed., Reshaping Museum Space: Architecture, Design, Exhibition, Museum Meanings (London: Routledge, 2005), 232f.
} 
the practice of curators, because the exhibition is about the Holocaust and not about museology. They also reject the organisation of the exhibition narrative in a less linear fashion which would allow visitors to explore specific geographical perspectives on the Holocaust and thus reflect on various ways of perceiving, interpreting, learning about and emplotting the events which are today summarised under the label 'Holocaust'. ${ }^{17}$

With this general characterisation of the IWM Holocaust exhibition in mind we now turn to the question central to this paper which was prompted by the observation that the IWM defines the Holocaust chiefly as the exclusion, persecution and murder of Jews. I am seeking to understand how the exhibition communicates who 'Jews' are and what is 'Jewish' in the IWM's interpretation of the victims' culture(s) and lives. As argued at the outset, the representations of Jewishness offered by the IWM Holocaust exhibition need to connect with the visitors' image of Jews to be able to facilitate learning about the people who became victims, confirming, challenging and/or subverting preconceptions visitors may hold about Jews. What is imagined to be a 'normative' expression of Jewish identity is therefore worth asking when examining the techniques the museum uses to establish the ethnic and/or cultural identity of victims who are central to the exhibition narrative.

\section{Photographs and Fewishness}

How, then, does the visitor learn about the Jewishness of the victims? ${ }^{18}$ What makes the victims Jewish in the representational strategy of the IWM? The photographs in the opening area of the exhibition are intended to depict 'Life before the Nazis' and are supposed to allow the visitor to gather their thoughts in preparation for the exhibition proper. ${ }^{19}$ The display includes pictures of traditional orthodox men and a bar mitzvah boy. The silent film playing in this area includes images of Jewish men in traditional Hasidic dress and the video testimony makes references to religious ritual. While not explored at that stage, references to Jewish religious practice are taken up again in the showcase on Jewish life which is surrounded by a display of antisemitic writings and posters and placed in the alcove which explains the history of antisemitism. The alcove also shows a specially produced film which explains in two sections: 'Who are the Jews?' and 'How did antisemitism arise?' The curators wish to make the point that Jewish life always existed alongside antisemitism. And yet, the arrangement may suggest more than that, in particular when the subtle interpretive hint of the placement of artefacts relating to Jewish life on a white background and the display of antisemitic goods on a black background is overlooked. Then the seemingly indiscriminate intermingling of antisemitic works with artefacts of Jewish life suggests that Jewish life should be interpreted with the help of antisemitic works, or the display can be read as Jewish life

\footnotetext{
${ }^{17}$ Interview with Taylor and Salmons, 4 July 2008; cf. also Pieper, Musealisierung des Holocaust, 29.

18 The following discussion excludes the minority of victims who were persecuted as Jews but who did not identify themselves as Jewish.

19 The Holocaust exhibition differs from the other permanent exhibitions in the IWM which, as the name of the museum already indicates, deal primarily with war from a British perspective. The visitor, who leaves the large open space at the centre of the museum filled with the machinery of war such as tanks and planes of both world wars, and turns to the Holocaust exhibition on the 4th floor, is given a moment of collection and orientation in this foyer to the exhibition proper.
} 
conforming to - or even confirming? - antisemitic views of Jews. ${ }^{20}$ Rupnow's question as to whether today's Holocaust exhibitions may unintentionally reproduce Nazi models of representing Jewish history and culture is particularly pertinent here, since the narrative of the IWM exhibition is closely linked to the perspective of the perpetrators and evidence produced by the victimisers. ${ }^{21}$

A dedicated exploration of Jewish culture in Europe before the Holocaust is lacking in the IWM Holocaust exhibition. The minutes of the meetings of the Advisory Group to the Holocaust Exhibition Project Team at the IWM indicate that there were recurrent intense debates on this subject. ${ }^{22}$ In particular in the early stages of discussing the translation of the historical narrative into the exhibition design, some members repeatedly voiced the fear that the upper floor of the exhibition lacked a section on Jewish life before the Nazis and 'that there was a danger that the Museum might end up teaching antisemitism by using material created by the Nazis and that their distortions would not be conveyed. ${ }^{23}$ The board concluded that 'an ethnographic approach would be out of place', ${ }^{24}$ because the subject of the exhibition is the murder of Jews and how the genocide came about, not Jewish history as such. As a result, Jewishness is mainly encountered through artefacts such as an intact Torah scroll in the showcase on Jewish life and antisemitism, a burnt Torah scroll in the 'Kristallnacht' display, a part of a Torah scroll which was hidden in the Warsaw ghetto and the remains of a Torah scroll found in Hannover in the display about the discovery of the camps by the Allies.

Jewishness is also referenced through photographs of 'recognisably Jewish" ${ }^{25}$ Jews - in contrast to assimilated Jews who are visually indistinguishable from their non-Jewish compatriots - a strategy which plays on antisemitic stereotypes and this may compound Nazi antisemitic renditions of Jewish life. The space addressing the ghettos - which concentrates on Warsaw and Lodz - contains a section on 'Spiritual Resistance' which assembles material relating to cultural activities such as theatre performances as well as religious services. Among other items, such as the Torah scroll already mentioned, we find a list of rabbis authorised by the local 'Jewish Council' to perform weddings in the Lodz ghetto, marriage documents and photographs of religious ceremonies such as a wedding and a circumcision. It is not clear who took the photos displayed in this section and who can be seen in these photos. Some photographs which depict the conditions inside ghetto tenements and workshops are likely to be self-portrayals of the ghetto inhabitants, evidently

${ }^{20}$ Cf. also Tony Kushner, 'The Holocaust and the Museum World in Britain: A Study of Ethnography' in Sue Vice, ed., Representing the Holocaust: In Honour of Bryan Burns (Vallentine Mitchell, London, 2003), 24f; K. Hannah Holtschneider, 'Victims, Perpetrators, Bystanders? Witnessing, Remembering and the Ethics of Representation in Museums of the Holocaust' in Holocaust Studies 13:1 (2007), $91 \mathrm{f}$.

${ }^{21}$ It is possible that all attempts to contrast the perpetrator perspective with self-representations of victims are not enough to subvert antisemitic interpretations of Jewish life. For example, in the display about the T4 Euthanasia programme images of children who were subjected to medical experiments are, where available, juxtaposed with family photographs of the same children, in order to challenge the perspective of the images produced by perpetrators (Interview with Taylor and Salmons, 4 July 2008). Such a display strategy is not followed for the representation of Jews, nor would it necessarily always be possible to do so.

${ }_{22}$ Archival materials relating to the creation of the Holocaust exhibition are located in the IWM.

${ }^{23}$ Minutes of the third meeting of the Advisory Group 12 June 1997. The topic was also discussed at the Group's fourth meeting on 20 April 1998 when it was made clear that 'The Museum had decided not to devote a specific section to the subject but was still dealing with it in prominent and easily accessible places'. The topic surfaced again at Group's meeting on 23 April 1999 when the exhibition was already physically under construction.

${ }^{24}$ Minutes of the third meeting of the Advisory Group 12 June 1997.

${ }_{25}$ Minutes of Advisory Group meeting 23 April 1999. 
taken with the approval of those pictured. Other photographs show smugglers at work, the photographer having been positioned such that neither the SS nor the smugglers were able to observe the camera. In addition, there are images of street life which have a documentary character and it is difficult to tell who may have taken them. Ghetto inhabitants included professional photographers who continued their work, regularly publishing in ghetto newspapers, documenting the work of the respective ghetto's fudenrat and also accumulating a photographic record of their surroundings for themselves. ${ }^{26}$ Since the majority of the images in this section are labelled only in order to provide an account of what is visible, but not who took the photo and what we know of the conditions in and the purpose for which the photo was taken, the visitor is left with no help to decipher the photographic illustrations which accompany the narrative of destruction. This display is one of the last opportunities in the exhibition narrative to have photographic evidence of the victims' interpretations of their lives at the time the events were unfolding.

The photos in the ghetto section function as illustrations of the text panel and are not artefacts in their own right, which explains why captions were often deemed unnecessary. This contrasts with the much more detailed depiction of the 'industry of murder', which names responsible individuals (albeit in a token effort) and describes their functions in the murder process. The victims, although identified on video testimony and in display cases addressing the fate of individuals, are almost always representative of 'everyman' or part of an anonymous mass of photographs and not the leaders of communities or individuals who carried responsibility for larger groups of people. To name only a few better known examples, one misses prominent reference to the leaders of Jewish Councils or to leading rabbis, or to the group associated with the historian Emmanuel Ringelblum which gathered evidence of the murder process in the Warsaw ghetto.

Religious Jews were deemed to be 'recognisably Jewish' by the Advisory Group and there the question arises what function is served by displaying 'recognisably Jewish' Jews. One possibility is that it is an acknowledgement that the majority of those who were murdered in the Holocaust came from communities which lived a traditional lifestyle and to whom what we now identify as religiously Jewish dress and comportment was 'normative', everyday, allencompassing. Or it may be a reflection of the iconic stereotypes of a Jewish 'normativity' which visitors to the exhibition are thought to expect when looking for/at Jews. It appears that those not 'recognisably Jewish' Jews are perceived as 'normal', implicitly suggesting that the visitor has a mental map on which to pinpoint what is 'normal' ('normative'?) in the 1930s in particular in Germany. That which is 'normal' does not seem to need much referencing. Conversely, the 'recognisably Jewish' Jews share the attributes of 'foreign' and 'exotic'. The only resonance in the exhibition for 'foreign' and 'exotic' are antisemitic descriptions of 'the Jew' which characterise the object of their hatred precisely as alien and not belonging, hence needing to be expelled or otherwise gotten rid of.

There are no sections in the exhibition which would introduce the culture which traditional 'recognisably Jewish' people inhabited. The video installations in the entrance cone and in the section on the Warsaw ghetto show scenes of pre-war Jewish life, mainly in shtetls in Poland, but these are not commented upon. In these Jewish men in traditional grab are pictured alongside women dressed in the latest fashion, families which include people dressed

\footnotetext{
${ }^{26}$ Cf. for example Janina Struk, Photographing the Holocaust: Interpretations of the Evidence (London: I.B. Tauris, 2004).
} 
traditionally and individuals whose clothes are indistinguishable from those of non-Jews. Some survivor testimony demonstrates that many families were divided by their religious observance or lack thereof. And yet, it is difficult, if not impossible, to gather a clearer idea of the religious identifications of Jewish Holocaust victims, in particular notions that go beyond a stereotypical 'normativity'. Such references to 'recognisably Jewish' Jews inscribe at best a stereotypical and at worst an antisemitic 'normativity' in representations of Jews.

It seems that photographs of 'recognisably Jewish' Jews are primarily used to point to a version of 'Jewishness' that is instantly recognisable by visitors and that thereby suggests a certain 'normativity'. To have the effect of recognition, it does not seem to matter to the curators who pressed the shutter on the camera or for which purpose the photographs were produced. Hence, perpetrator evidence is employed to tell the story of the Holocaust without reflection on possible implications of using material of victimiser origin, such as prior ideological uses it may have been put to. The corollary of this use of photographs of religious Jews is a reinforcement of antisemitic perspectives on Jewishness which the exhibition has a hard time undercutting. Because these people themselves are at no point given the voice to speak about their own lives, self-understandings and interpretation of the events that made them into victims, the visitor has to rely on interpreting their Jewishness through the implicit messages embedded in the visual clues given by the exhibition - or bring their own independent knowledge to interpret these images. As a result, the fear of members of the Advisory Group that antisemitic images might come to dominate the exhibition appears to have been realised, despite the significant changes to the displays in response to the designers' first proposal.

As already mentioned, the majority of the photographs displayed in the exhibition were taken by victimisers and even if the curators intend to 'stake a new explanatory context [which] can overcome their original purpose ${ }^{\prime 27}$, this, as Paul Williams argues, does not alter the fact that

for victims, the camera was itself an instrument of humiliation and psychological torture. By displaying their pictures, there is a valid fear that museums might perpetuate this original intent, forcing those pictured to remain in submissive subjugation..${ }^{28}$

The indiscriminate display of photographs taken by victims of themselves before they became victims, of victims in their situation of being persecuted, and of perpetrators documenting their deeds treats photographs in the same way as the exhibition treats survivor testimony: as illustration, rather than historical evidence in their own right. ${ }^{29}$ Many but by no means all images are captioned, and the captions identify photographs mainly in their relation to the theme of the main display, that is, they provide an identification of the location at which they were taken and who or what they show. Captions of photographs (and artefacts) use the smallest font size, thus making them more difficult to read. In addition the visitor can only detect the origins of the photographs through a detailed scrutiny of the camera angle and frame of individual pictures, and can then speculate about the journey of the images until they ended up in this particular exhibition. In view of the sheer amount

\footnotetext{
27 Paul Williams, Memorial Museums: The Global Rush to Commemorate Atrocities (Oxford: Berg, 2007), 57.

${ }^{28}$ Williams, Memorial Museums, 57.

${ }^{29}$ Cf. also Isabel Wollaston, 'Negotiating the Marketplace: The Role(s) of Holocaust Museums Today', in fournal of Modern Ferwish Studies 4 (2005), 4, 69.
} 
of photographs in the exhibition and their frequent assembly in collages it is unrealistic to expect a visitor to perform such detailed analyses. This approach leaves unexplored the different perspectives the photographers took towards their subjects, as well as the various purposes for taking photos and the co-operation (or lack thereof) of the subjects, aspects of a photograph's origin and history which can yield important historical information and encourage the viewer to reflect on their own relationship to the images. ${ }^{30}$

\section{Photographs in the context of the entire exhibition}

In the IWM Holocaust exhibition photographs illustrate, giving a visual context for the textual explanations and the placement of historical artefacts, and photographs create atmosphere and set the tone of the exhibition. At points photographs also authenticate the narrative, saying 'this really happened'. This latter function of photographs is particularly evident when images are used to authenticate original artefacts. For example, the display on the ghettos includes a section on the Warsaw ghetto, part of which focuses on an impressive and gruesome artefact: a cart which transported corpses through the streets of the ghetto. The wall in front of which the restored cart is exhibited is covered with an enlarged photograph of just such a cart in use in the Warsaw ghetto. This linking of image and object points to the authenticity of the artefact: the tangible object here in the museum really was there in the Warsaw ghetto. ${ }^{31}$ This suggests that in some cases neither the photograph nor the historical artefact alone are deemed 'authentic' enough, but need each other in order to establish conclusively that 'this has been' ${ }^{32}$ While objects are trusted to convey a sense of historical reality in the exhibition, photographs do not seem to possess such an aura, possibly because they are used for many different purposes: sometimes as historical evidence, sometimes as background which creates a mood and to reinforce emotional messages. Enlarged photographs are used specifically when the cruelty of the perpetrators and the outrage and shock over their deeds is supposed to be emphasised: for example, the close-up portraits of two young women, who were forcibly sterilised as part of the Rassehygieneprogramm, are supposed to lead the viewer to reflect about the character of those responsible, judges and doctors; ${ }^{33}$ or the large image on the wall behind a tabletop display case about the mass shootings of Lithuanian Jews, which shows a man kneeling at the edge of a mass grave he presumably helped to dig and a gun pointed at his head by a member of the Einsatzgruppe.

Thus, a threefold hierarchy of material in the narrative of the exhibition can be established: at the top sits the historical narrative which occupies the most significant place and is inseparable, secondly, from the historical artefacts employed to support it. Without narrative the artefacts would not be able to 'speak', but without artefacts the narrative would lack authentication. Artefacts of the Holocaust by themselves would not be enough to persuade visitors to spend time in the exhibition. Curators repeatedly point to the fact that

\footnotetext{
${ }^{30}$ Cf. for example Hüppauf, Bernd, 'Emptying the Gaze: Framing Violence through the Viewfinder', New German Critique 72 (1997); Koch, Gertrud, Die Einstellung ist die Einstellung: Visuelle Konstruktionen des Judentums (Frankfurt am Main: Suhrkamp, 1992).

31 The connection is made, even though it should be clear to the visitor that the cart on the photographs is probably not identical with the cart on display.

32 Interview with Suzanne Bardgett, 01 July 2008.

${ }^{33}$ Interview with Bardgett, 01 July 2008.
} 
the historical objects associated with the Holocaust are not spectacular or aesthetically pleasing to look at, and therefore need emplotting in a captivating (linear) narrative to entice the visitor to contemplate for example old shoes or a metal spoon. ${ }^{34}$ Thus the artefacts need the narrative and vice versa. In last place, therefore, we find the photographs which are, strictly speaking, not necessary for structuring the exhibition narrative ${ }^{35}$ Photographs do not authenticate the narrative by themselves, they can only second what the artefacts prove, or verify the veracity of artefacts. Photographs, visitors know, can be manipulated - a mistrust that is less frequently associated with artefacts due to the authority held by the museum as a social and cultural institution. ${ }^{36}$

\section{Who are 'Jewe' in the IWM Holocaust exhibition?'}

The IWM Holocaust exhibition seems to oscillate between two conflicting demands. On the one hand, the historical meta-narrative, told from the perspective of the Nazi perpetrators, demands that the victims of the Holocaust are defined, via Nazi racist criteria, as Jews. At the same time, the exhibition tries to subvert antisemitic interpretations of Jewish life and history through video testimony and the presentation of ritual objects which articulate Jewish self-understanding and thus are supposed to clarify for the visitor that Jewish selfunderstandings did not coincide with Nazi interpretations of 'who is a Jew'.

On the other hand, the exhibition also needs to forge an explicit link with the lives of their visitors who, in the overwhelming majority, are not Jewish and have no close ties to those who were victims of the Holocaust. This is where photographs of Jews who do not look 'recognisably Jewish' are employed. Visitors are supposed to experience that Jews are as 'normal' and 'human' as they are themselves, and therefore the exhibition needs to offer the possibility of identification for visitors in an environment that lacks aesthetic or historically fascinating objects. The IWM curators, following the educational directives of the USHMM, believe that the Holocaust 'yields critical lessons for an investigation of human behaviour ... [and] ... what it means to be a responsible citizen. ${ }^{\cdot 37}$ Hence, the exhibition seems to wish to keep the category 'victim' as neutral as possible so that it becomes an approximation of a stereotypical ('normative'?) 'Western European' on which the visitor can inscribe their own circumstances and hopes. ${ }^{38}$ Thus, 'Jews' can no longer be employed to represent a specific

\footnotetext{
${ }^{34}$ Interview with Taylor and Salmons, 4 July 2008.

${ }_{35}$ Although at the beginning of the curatorial process the concern was raised that artefacts may be difficult to locate and that the narrative of the history of the Holocaust may have to rely on photographs and film (cf. Suzanne Bardgett, 'Film and the Making of the Imperial War Museum's Holocaust Exhibition' in Toby Haggith and Joanna Newman, eds., Holocaust and the Moving Image: Representations in Film and Television since 1933 [London: Wallflower, 2005], 20).

${ }^{36}$ When photographs are treated as historical artefacts and exclusive evidence, such as in the Crimes of the Wehrmacht exhibition, the discovery that some may have been captioned wrongly may lead to challenging the reliability of the historical claims made by the entire exhibition (cf. for example Christian Hartmann, Johannes Hürter, and Ulrike Jureit, eds., Verbrechen der Wehrmacht: Bilanz einer Debatte, Beck'sche Reihe 1632 [München: C.H. Beck, 2005]).

${ }^{37}$ David Cesarani, 'Should Britain Have a National Holocaust Museum?' in fournal of Holocaust Education 7:3 (1998), 17-27.

${ }^{38}$ See also Kushner's argument that such an approach to the Holocaust is in continuity with historical American and British liberal perspectives on the genocide of Jews in Europe: Tony Kushner, The Holocaust and the Liberal Imagination: A Social and Cultural History (Oxford: Blackwell, 1994).
} 
people with complex and divergent histories and identifications or as members of particular culture(s) and minorities in various European societies. Rather than challenging visitor preconceptions of who Jews are, the exhibition creates two versions of Jewish 'normativity', one that relies on antisemitic stereotypes and another which assimilates Jews into a gentile Western secular norm.

As a result the geographical and cultural diversity of those who became victims of the Holocaust is increasingly difficult to represent. The curators rejected a preface to the exhibition which addresses 'the culture(s) that was/were lost' because the IWM does not deal in ethnography. Hence, the visitor without prior knowledge of Jewish history in Europe is left with a very vague idea of the cultural, religious, social and political affiliations and allegiances of the people who were murdered during the Holocaust. The curators rejected arranging the narrative according to the perspectives of various groups of Jewish victims, because this was deemed too parochial and lacking authority and overall clarity. Another reason may be the assumption that the majority of visitors will not view the exhibition more than once. Since the pedagogical aim is to leave every visitor with a clear framework of the 'key events' of the Holocaust, the narrative has to offer a logical sequence of events to aid the establishment of the Holocaust in the visitor's mind as a unified and structured whole.

The intention of the IWM exhibition is to tell the story of destruction and not to talk about what was destroyed. This difference in emphasis alone may account for the dominance of perpetrator images of victims. And as such it may be an inevitable consequence of the construction of the exhibition narrative. Yet, it is important to reflect on possible consequences of this choice of representation for the understanding and interpretations of the Jewishness of the victims of the Holocaust for those who visit the exhibition without extensive prior knowledge of Jewish history, culture and religion. If one consequence is the tacit reinforcement of antisemitic constructions of Jewishness, this arguably is a high price to pay for the adoption of this narrative of Holocaust history. Bluntly put: is antisemitism an acceptable by-product of a clearly structured linear narrative of the Holocaust?

Arguably, then, Holocaust victims in the IWM Holocaust exhibition are Jewish only in the sense in which their Jewishness can be linked a) to the explication of their murder - offering Nazi views of their victims - and b) to the expression of their humanity as equivalent to that of the museum visitors. Both strategies of representing Jewishness obliterate Jewish selfunderstandings and the complexities of pre-war Jewish culture, albeit, one hopes, unwittingly and without malicious intent.

\section{BIBLIOGRAPHY}

Bardgett, Suzanne, 'Film and the Making of the Imperial War Museum's Holocaust Exhibition' in Toby Haggith and Joanna Newman, eds., Holocaust and the Moving Image: Representations in Film and Television since 1933 (London: Wallflower, 2005), 19-25.

Cesarani, David, 'Should Britain Have a National Holocaust Museum?' Fournal of Holocaust Education 7:3 (1998), 17-27.

Greenberg, Stephen, 'The Vital Museum' in Suzanne MacLeod, ed., Reshaping Museum Space: Architecture, Design, Exhibition, Museum Meanings (London: Routledge, 2005), 226-237.

Hamann, Christoph, Visual History und Geschichtsdidaktik: Bildkompetenz in der historisch-politischen Bildung, Geschichtswissenschaft 53 (Herbolzheim: Centaurus Verlag, 2007). 
Hartmann, Christian, Johannes Hürter, and Ulrike Jureit, eds., Verbrechen der Wehrmacht: Bilanz einer Debatte, Beck'sche Reihe 1632 (München: C.H. Beck, 2005).

Holtschneider, K. Hannah, 'Victims, Perpetrators, Bystanders? Witnessing, Remembering and the Ethics of Representation in Museums of the Holocaust', Holocaust Studies 13:1 (2007), 84-104.

Hüppauf, Bernd, 'Emptying the Gaze: Framing Violence through the Viewfinder', New German Critique 72 (1997), 3-44.

Koch, Gertrud, Die Einstellung ist die Einstellung: Visuelle Konstruktionen des fudentums (Frankfurt am Main: Suhrkamp, 1992).

Kushner, Tony, The Holocaust and the Liberal Imagination: A Social and Cultural History (Oxford: Blackwell, 1994).

Kushner, Tony, 'The Holocaust and the Museum World in Britain: A Study of Ethnography' in Sue Vice, ed., Representing the Holocaust: In Honour of Bryan Burns (Vallentine Mitchell, London, 2003), $13-40$.

Liss, Andrea, Trespassing through Shadows: Memory, Photography, and the Holocaust (Minneapolis, MN: University of Minnesota Press, 1998).

Loewy, Hanno, “ “ $\ldots$ without Masks”: Jews through the Lens of "German Photography” 1933-1945' in Klaus Honnef, Rolf Sachsse, and Karin Thomas, eds., German Photography 1870-1970: Power of a Medium (Köln: DuMont Buchverlag, 1997), 100-114.

Pieper, Katrin, Musealisierung des Holocaust: Das füdische Museum Berlin und das U.S. Holocaust Memorial Museum in Washington D. C. Ein Vergleich (Köln: Böhlau Verlag, 2006).

Rupnow, Dirk, Vernichten und Erinnern: Spuren nationalsozialistischer Gedächtnispolitik (Göttingen: Wallstein Verlag, 2005).

Stier, Oren Baruch, Committed to Memory: Cultural Mediations of the Holocaust (Amherst, MA: University of Massachusetts Press, 2003).

Struk, Janina, Photographing the Holocaust: Interpretations of the Evidence (London: I.B. Tauris, 2004).

Williams, Paul, Memorial Museums: The Global Rush to Commemorate Atrocities (Oxford: Berg, 2007).

Wollaston, Isabel, 'Negotiating the Marketplace: The Role(s) of Holocaust Museums Today', fournal of Modern Fewish Studies 4 (2005), 63-80. 